\title{
Severe anaphylaxis during sentinel lymph node biopsy (SLNB)
}

\author{
Andreia Ferrão Vasconcelos Pinela ${ }^{1 *}$, Cintia Cruz $^{2}$, Elza Tomaz ${ }^{2}$, Filipe Inacio ${ }^{2}$ \\ From 6th Drug Hypersensitivity Meeting (DHM 6) \\ Bern, Switzerland. 9-12 April 2014
}

The aim of this study was to present two cases of severe anaphylaxis during sentinel lymph node biopsy (SLNB). Case 1: A 64-year-old-woman had two months earlier been diagnosed with breast ductal invasive carcinoma by first local excision. She was taken for further surgery with SLNB. At induction she received midazolam, fentanyl, propofol, atracurium, cefazolin and paracetamol. She was given a subcutaneous injection of the dye Patent Blue V (PBV) and shortly afterward she developed a blue rash over her abdomen and her blood pressure dropped precipitously. She was treated successfully with intravenous adrenaline and fluids. Six weeks later, a skin prick test (SPT) and intradermal test (ID) to all used drugs, latex and B-lactamics were performed. SPT and ID to PBV were positive with $3 \mathrm{~mm}$ and $6.5 \mathrm{~m}$ in weal diameter. ID test to cefazolin was also positive $(6.5 \mathrm{~mm})$. All others were negative. Case 2: A 49-year-old woman required local excision of a breast lump with SLNB. She received midazolam, fentanyl, cefazolin and atracurium. PBV was then injected and $15 \mathrm{~min}$ later, she developed generalized erythema and severe hypotension and bradycardia. She required, intravenous adrenaline and amines infusion postanaesthetic. SPT and ID to all used drugs, latex and B-lactamics were performed. SPT to PBV diluition 1:100 and 1:10 were positive with $3 \mathrm{~mm}$ and $8 \mathrm{~mm}$ in weal diameter. The ID testing of atracurio in major concentration of 1:1000 revealed a $7 \mathrm{~mm}$ increase in the weal. All others were negative.

\section{Discussion}

In case 1 the PBV positive test, the blue rash, and the positive test to cefazolin with negative B-lactamic test indicate a type I allergy towards PBV as a more probable cause of the perioperative anaphylaxis and a selective sensibilization to cefalosporins. In case 2 the positive reaction to

${ }^{1}$ Hospital da Misericórdia de Évora, Department of Immuno-allergology, Portugal

Full list of author information is available at the end of the article
SPT to PBV suggest the diagnosis of patent blue anaphylaxis. The positive ID test to atracurium in major concentration is probably indicative of an irritant. The etiological diagnosis in perioperative anaphylaxis remains complex and often difficult to accomplish.

\section{Authors' details}

'Hospital da Misericórdia de Évora, Department of Immuno-allergology, Portugal. ${ }^{2}$ Centro Hospitalar Setúbal, Department of Immuno-allergology, Portugal.

Published: 18 July 2014

doi:10.1186/2045-7022-4-S3-P5

Cite this article as: Pinela et al.: Severe anaphylaxis during sentinel lymph node biopsy (SLNB). Clinical and Translational Allergy 2014 4(Suppl 3):P5.
Submit your next manuscript to BioMed Central and take full advantage of:

- Convenient online submission

- Thorough peer review

- No space constraints or color figure charges

- Immediate publication on acceptance

- Inclusion in PubMed, CAS, Scopus and Google Scholar

- Research which is freely available for redistribution
() Biomed Central
C BioMed Central

(c) 2014 Pinela et al; licensee BioMed Central Ltd. This is an Open Access article distributed under the terms of the Creative Commons Attribution License (http://creativecommons.org/licenses/by/4.0), which permits unrestricted use, distribution, and reproduction in any medium, provided the original work is properly cited. The Creative Commons Public Domain Dedication waiver (http:// creativecommons.org/publicdomain/zero/1.0/) applies to the data made available in this article, unless otherwise stated. 